\title{
Penilaian Properti Psikometrik Instrumen Kualitas Hidup (HRQoL) pada Populasi Umum: Tinjauan Sistematik
}

\author{
Assessment of Psychometric Properties Quality of Life Instruments (HRQoL) in General Populations: \\ Systematic Review
}

Restu Nur Hasanah Haris*, Rahmat Makmur, Tri Murti Andayani, Susi Ari Kristina

Fakultas Farmasi, Universitas Gadjah Mada, Yogyakarta

Submitted: 26-12-2018 Revised: 26-01-2019 Accepted: 25-03-2019

Korespondensi : Restu Nur Hasanah Haris : Email : restuharis.apt@gmail.com

\begin{abstract}
ABSTRAK
Kualitas hidup (HRQoL) merupakan ukuran kesehatan seseorang dalam fungsi fisik, spiritual, emosional dan peran dalam masyarakat. Pengukuran kualitas hidup (HRQoL) merupakan hal yang penting untuk diketahui dan dievaluasi. Pengukuran yang dilakukan tidak hanya pada pasien semata tetapi juga dapat dilakukan pada populasi umum dengan penggunaan instrumen spesifik ataupun generik. Instrumen yang digunakan memerlukan sebuah pengujian properti psikometrik guna memastikan tingkat validitas dan reliabilitasnya. Artikel ini bertujuan untuk melakukan tinjauan sistematik terkait penilaian properti psikometrik pada instrumen kualitas hidup (HRQoL) pada populasi umum. Pencarian artikel dimulai sejak 1-5 desember 2018 berasal dari pubmed dan google scholar. Penilaian dilakukan dengan menggunakan checklist properties sesuai dengan kriteria cohen. Penilaian terkait content validity, construct validity, internal consistency reliability, test-retest, ceiling effect dan tingkat kredibiltas instrumen yang digunakan. Hasil tinjauan kami sebanyak 80 artikel didapatkan dengan 24 artikel memenuhi kriteria inklusi. Instrumen Short Form-36 (SF-36) merupakan instrumen yang paling banyak digunakan dalam mengukur kualitas hidup pada populasi umum (26,6\%). Beberapa instrumen belum melakukan pengujian sesuai dengan kriteria, hampir semua instrumen menunjukan tingkat validasi yang baik dengan construct validity menggunakan convergent dan discriminat validity dengan nilai cronbach alpha $>0,7$. Test-retest reliability memberikan korelasi yang baik. Beberapa instrumen menunjukan adanya ceiling effect. Penilaian tingkat kredibilitas Instrumen Short Form-36 (SF-36), Short Form-6 Dimension (SF-6D), European Quality-Five Dimension (EQ-5D), Short Form-12 (SF-12) dan Pediatric Quality of Life (PedsQoL) dinilai sebagai instrumen yang establish. Diperlukan pengujian validasi lebih lanjut untuk memberikan dan mendukung pengukuran instrumen kualitas hidup (HRQoL) selanjutnya.

Kata kunci: properti psikometrik, instrumen kualitas hidup (HRQoL), populasi umum.
\end{abstract}

\begin{abstract}
Quality of life (HRQoL) is a measure of a person's health in physical, spiritual, and emotional, and role functions in the society. Measurement of quality of life (HRQoL) is an important thing to understand and evaluate. Measurements are carried out not only on patients but also on the general population with the use of specific or generic instruments. The instrument used requires a psychometric properties test to ensure its validity and reliability. This article aims to conduct a systematic review of the psychometric properties of quality of life ( $\mathrm{HRQOL}$ ) instruments in the general population. Articles were collected in December 1st to 5th, 2018, from Pubmed and Google Scholar. The assessment was carried out using the checklist properties according to the Cohen criteria and included the content validity, construct validity, internal consistency reliability, test-retest, ceiling effect and the level of credibility of the instruments. Among 80 articles obtained there were 24 articles that fulfilled the inclusion criteria. Short Form-36 (SF36) instrument is the most widely used instrument in measuring the quality of life in the general population (26.6\%). Some instruments have not been tested according to the criteria, while almost all instruments show a good level of validation of construct validity using convergent and discriminant validity with Cronbach alpha values $>0.7$. Test-retest reliability provides a good correlation. Some instruments show a ceiling effect. According to the assessment, the SF-36, SF-6D, EQ-5D, SF-12 and PedsQoL instruments are considered as established instruments. Further validation testing is needed to provide and support the measurement of subsequent quality of life (HRQoL) instruments.

Keywords: psychometric properties, HRQoL Instruments, general population.
\end{abstract}

JMPF Vol 9(2), 2019 | DOI : 10.22146/jmpf.41911 


\section{PENDAHULUAN}

Kualitas hidup merupakan persepsi seseorang terkait kesehatan yang dimiliki menyangkut fungsi fisik, spritual, sosial dan perannya di masyarakat. Penting untuk mengetahui dan mengevaluasi fungsi fisik, spritual, sosial dan peran setiap individu yang ada $^{1}$.Dikatakan bahwa seseorang dengan kualitas hidup yang baik adalah individu yang mampu menjalankan fungsi dan perannya dalam kehidupan sehari-hari dengan baik pula. Pengukuran kualitas hidup (HRQoL) tidak terbatas hanya pada populasi sakit saja, tetapi juga dapat dilakukan pada populasi umum dalam hal ini adalah individu yang sehat, hal ini dapat ditemukan dengan banyaknya penelitian yang mengukur tingkat kualitas hidup pada populasi umum di berbagai negara.

Dalam pengukuran kualitas hidup kita dapat menggunakan pilihan instrumen generik maupun spesifik. Beberapa penelitian pengukuran HRQoL dengan instrumen generik digunakan pada populasi umum dan instrumen spesifik dilakukan pada pasien penyakit tertentu. Penggunaan instrumen spesifik dapat melihat bagaimana dampak sebuah penyakit terhdap kualitas hidup tiap individu sedangkan pada populasi umum evaluasi dapat membandingkan HRQoL dengan beban ekonomi di suatu negara ${ }^{2}$. Pengukuran HRQoL dengan menggunakan instrumen dilakukan pengujian properti psikometrik. Pengujian tersebut untuk menilai bagaimana tingkat validitas dan reliabilitas sebuah instrumen dalam mengukur kualitas hidup ${ }^{3}$. Penelitian terkait validasi instrumen telah berkembang dan banyak dilakukan baik pada populasi umum ataupun pada pasien tertentu.

Tujuan dari artikel ini adalah melakukan tinjauan sistematik pada instrumen HRQoL pada populasi umum dan menilai properti psikometrik yang dilakukan dengan menggunakan checklist properties sesuai kriteria.

\section{METODE}

Tinjauan sistematik terkait penilaian properti psikometrik pada instrumen kualitas hidup (HRQoL) menggunakan PRISMA, digunakan untuk membantu pemilihan artikel yang akan dinilai (Gambar 1).

\section{Strategi pencarian}

Pencarian artikel dimulai sejak 1-5 Desember 2018 yang dilakukan oleh 2 orang peneliti. Untuk memudahkan pencarian dalam penyusun sistematik ini, peneliti melakukan pencarian artikel dengan beberapa strategi dan penggunakan kata kunci, meliputi:

1. Populasi target: populasi umum.

2. Construct: Kualitas hidup (HRQoL), pengembangan dan translasi kuesioner, instrumen generik.

3. Pscychometric properties: validasi, content validity, face validity, construct validity, convergent validity, discriminant validity, known group validity, reliabilitas, internal consistency, test-retest, ceiling effect, dll.

\section{Kriteria inklusi}

Dalam tinjauan sistematik ini, kriteria inklusi yang dimasukan adalah jenis artikel yang merupakan original research bukan dalam bentuk review literatur, comment, ataupun systematic review lainnya, artikel diterbitkan dalam 10 tahun terakhir (2008-2018), artikel dalam bahasa inggris, tersedia secara lengkap (full text) tidak hanya mencantumkan bagian abstrak saja. Artikel tersebut memuat terkait pengukuran properti psikometrik baik itu validasi, reliabilitas, maupun responsivitas instrumen HRQoL pada populasi umum. Secara independen 2 orang peneliti melakukan screening pada setiap artikel yang akan direview, menelaah abstrak dan mencari referensi lain untuk mendapatkan informasi tambahan. Adanya perbedaan antara 2 peneliti diselesaikan dengan cara konsensus untuk mendapatkan keputusan bersama.

\section{Ekstrak data}

Data yang telah diterima dan masuk kriteria inklusi diekstrak kedalam tabel yang memuat tentang:

1. Instrumen kualitas hidup (HRQoL) pada populasi umum, menjelaskan terkait subyek/populasi umum, jumlah responden 


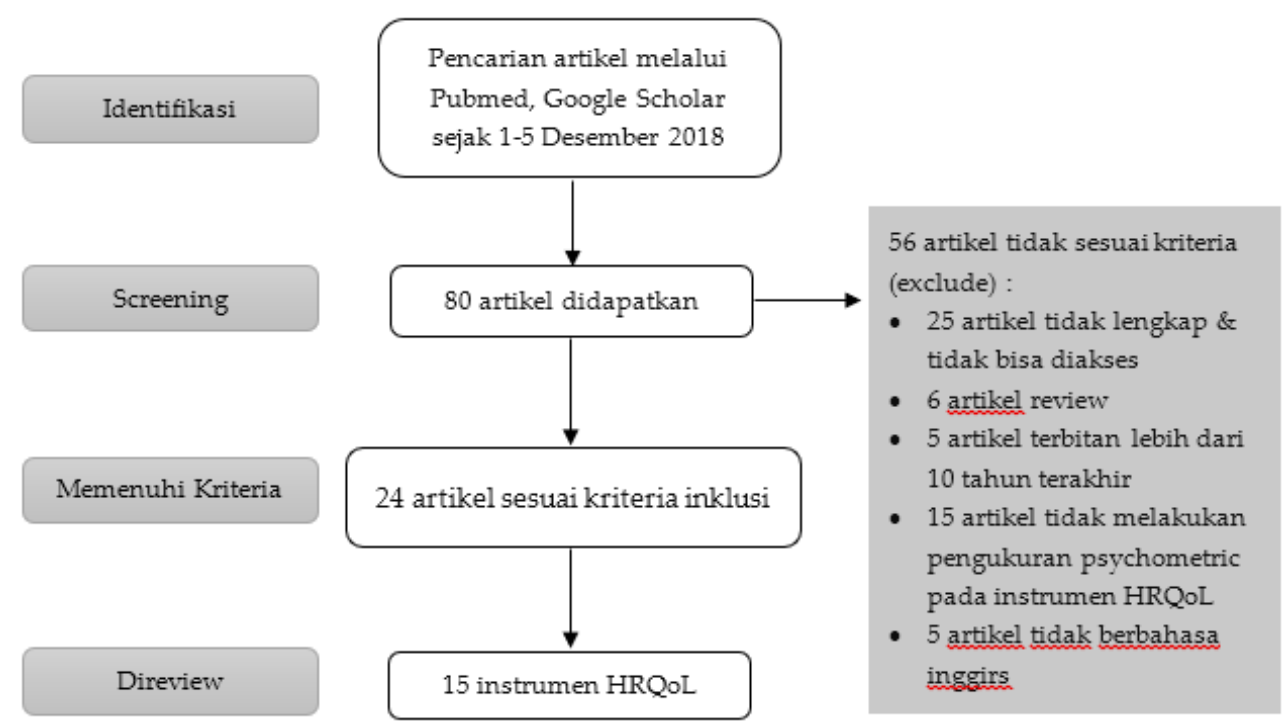

Gambar 1. Prisma diagram

yang ikut dalam penelitian dan penjelasan domain untuk tiap instrumen (Tabel I).

2. Pengukuran properti psikometrik: peneliti menilai pengukuran properti psikometrik yang telah dilakukan menggunakan properties checklist sesuai dengan guideline,menurut Terwee et al., ${ }^{4}$ (Tabel II). Meliputi: Reliabilitas (Internal consistency dan test-retest reliability), validasi (content validity, construct validity), dan ceiling effect.

Tingkat kredibilitas instrumen: mengikuti kriteria cohen ${ }^{4}$ yang dikelompokan menjadi 3 level: Well-established, Approaching well-established, Promising (Tabel III) ditinjau dari jumlah publikasi yang telah dilakukan dengan menggunakan instrumen tersebut dan sejauh mata pengukuran properti psikometrik disajikan.

\section{HASIL DAN PEMBAHASAN Hasil pencarian artikel}

Setelah melakukan pencarian artikel sejak 1-5 desember 2018 melalui pubmed dan google scholar, 80 artikel telah didapatkan. 24 artikel memenuhi kriteria inklusi. Total 56 artikel dikeluarkan dalam review karena tidak memenuhi kriteria yang diinginkan. 25 artikel tidak lengkap dan tidak bisa diakses, 6 artikel merupakan jenis artikel review, 5 artikel terbitan lebih dari 1 tahun terakhir, 15 artikel tidak melakukan pengukuran psychometric properties pada instrumen HRQoL dan 5 artikel lainnya tidak tersedia dalam dalam bahasa inggris pengukuran HRQoL dilakukan pada populasi umum dengan kategori dan jumlah responden yang beragam melalui wawancara/interview langsung ataupun survey online (email, telepon). Hasil dari tinjauan kami, dalam review ini ada 15 jenis instrumen yang digunakan dalam mengukur kualitas hidup (HRQOL) pada populasi umum. Instrumen HRQoL yang paling banyak digunakan adalah jenis instrumen Short Form-36 (SF-36) ${ }^{5,6,7,8}$ sebanyak 26,6\% dengan menggunakan pengujian psychometric properties yang beragam (Tabel I).

1. Short Form-36 (SF-36) $5,6,7,8$

2. Short Form-6 Dimension (SF-6D) $)^{9,10,11}$

3. European Quality-five-Dimension (EQ$5 \mathrm{D})^{12,13,14}$

4. Vécu et Santé Perçue de l'Adolescent (VSP-A) ${ }^{15}$

5. World Health of Quality of Life- BREF (WHOQOL-BREF) ${ }^{16,17}$

6. Short Form-12 (SF-12) ${ }^{18}$

7. Pediatric Quality of Life (PedsQL) ${ }^{19,20}$

8. Positive Mental Health Instrument $(\mathrm{PMH})^{21}$

9. The Four Dimensional Symptom Quesioner $(4 \mathrm{DSQ})^{22}$

10. WHO-Well being ${ }^{23}$ 
Tabel Ia. Instrumen Kualitas Hidup (HRQoL) pada Populasi Umum

\begin{tabular}{|c|c|c|c|c|}
\hline $\begin{array}{l}\text { Instrumen } \\
\text { HRQoL }\end{array}$ & $\begin{array}{c}\text { Populasi/ } \\
\text { Negara }\end{array}$ & Responden & $\begin{array}{c}\text { Penulis/ } \\
\text { Tahun }\end{array}$ & Domain \\
\hline SF-6D & China & 128 & $\begin{array}{c}\text { Lam } \\
(2008)^{10}\end{array}$ & $\begin{array}{l}\text { Domain: fungsi fisik, keterbatasan peran, } \\
\text { fungsi sosial, rasa sakit, kesehatan } \\
\text { mental dan vitalitas. }\end{array}$ \\
\hline EQ-5D-5L & Malaysia & 1137 & $\begin{array}{l}\text { Shafiee } \\
(2018)^{12}\end{array}$ & $\begin{array}{l}\text { Domain: mobilitas, perawatan diri, } \\
\text { kegiatan yang biasa dilakukan, rasa } \\
\text { sakit, kesehatan mental. VAS }\end{array}$ \\
\hline SF-36 & Thailand & 600 & $\begin{array}{c}\text { Kangwa } \\
\text { nrattana } \\
\text { kul } \\
(2018)^{5}\end{array}$ & $\begin{array}{l}\text { Domain: fungsi fisik, keterbatasan peran } \\
\text { masalah fisik, nyeri badan, persepsi } \\
\text { kesehatan umum, vitalitas, fungsi sosial, } \\
\text { fungsi sosial, keterbatasan peran karena } \\
\text { faktor emosional, kesehatan mental. }\end{array}$ \\
\hline VSP & Brazil & 446 & $\begin{array}{c}\text { Aires } \\
(2011)^{15}\end{array}$ & $\begin{array}{l}\text { Psikologi, domain fisik, vitalitas, } \\
\text { hubungan dengan guru, performa } \\
\text { disekolah, hubungan dengan teman, } \\
\text { hubungan dengan orangtua, tubuh, } \\
\text { aktivitas bersantai, sentimental dan } \\
\text { seksual. }\end{array}$ \\
\hline WHOQOL- & & 1164 & Nedjat & Domain: kesehatan fisik, kesehatan \\
\hline BREF & singapura & 3400 & $\begin{array}{l}(2008)^{16} \\
\text { Suarez } \\
(2018)^{17}\end{array}$ & $\begin{array}{l}\text { psikologi, hubungan sosial, kesehatan } \\
\text { lingkungan, item kesehatan umum. }\end{array}$ \\
\hline PedsQL & Belanda & 649 & $\begin{array}{r}\text { Limperg } \\
(2014)^{19}\end{array}$ & $\begin{array}{l}\text { Kesehatan fisik, fungsi emosional, fungsi } \\
\text { sosial, fungsi sosial, fungsi dalam } \\
\text { bekerja/sekolah, kesehatan psikologi. }\end{array}$ \\
\hline PMH & $\begin{array}{l}\text { Populasi } \\
\text { Asia }\end{array}$ & 1925 & $\begin{array}{l}\text { Vaingan } \\
\text { kar } \\
(2018)^{21}\end{array}$ & $\begin{array}{l}\text { Domain: umum, dukungan emosioanl, } \\
\text { spiritual, keahlian interpersonal, } \\
\text { pertumbuhan pribadi dan otonomi, } \\
\text { pengaruh global. }\end{array}$ \\
\hline SF-12-V2 & Korea & 1000 & $\begin{array}{l}\text { Kim } \\
(2014)^{18}\end{array}$ & $\begin{array}{l}\text { Domain: fungsi fisik, peran fisik, nyeri } \\
\text { badan, kesehatan umum, fungsi sosial, } \\
\text { vitalitas, peran emosional, kesehatan } \\
\text { mental }\end{array}$ \\
\hline PedsQL & Portugal & 179 & $\begin{array}{l}\text { Ferreira } \\
(2014)^{20}\end{array}$ & $\begin{array}{l}\text { Domain: Kesehatan fisik, fungsi } \\
\text { emosional, fungsi sosial, fungsi sosial, } \\
\text { fungsi dalam bekerja/sekolah, kesehatan } \\
\text { psikologi. }\end{array}$ \\
\hline 4DSQ & Belanda & 5273 & $\begin{array}{l}\text { Terluin } \\
(2016)^{22}\end{array}$ & $\begin{array}{l}\text { Gangguan/kesulitan, } \\
\text { kecemasan, somatization. }\end{array}$ \\
\hline SF-36 & $\begin{array}{l}\text { Norwegia } \\
\text { n Jordania } \\
\text { utara }\end{array}$ & $\begin{array}{c}9164 \\
511\end{array}$ & $\begin{array}{l}\text { Garratt } \\
(2017)^{6} \\
\text { Khader } \\
(2011)^{7}\end{array}$ & $\begin{array}{l}\text { Domain: fungsi fisik, keterbatasan peran } \\
\text { masalah fisik, nyeri badan, persepsi } \\
\text { kesehatan umum, vitalitas, fungsi sosial, } \\
\text { fungsi sosial, keterbatasan peran karena } \\
\text { faktor emosional, kesehatan mental. }\end{array}$ \\
\hline
\end{tabular}


Restu Nur Hasanah Haris, et al

Tabel Ib. Instrumen Kualitas Hidup (HRQoL) pada Populasi Umum

\begin{tabular}{|c|c|c|c|c|}
\hline $\begin{array}{l}\text { Instrumen } \\
\text { HRQoL }\end{array}$ & $\begin{array}{l}\text { Populasi/ } \\
\text { Negara }\end{array}$ & Responden & $\begin{array}{c}\text { Penulis/ } \\
\text { Tahun }\end{array}$ & Domain \\
\hline $\begin{array}{l}\text { WHO-5 \& } \\
\text { WHO-10 }\end{array}$ & Swedia & 4027 & $\begin{array}{c}\text { Löve } \\
(2013)^{23}\end{array}$ & $\begin{array}{l}\text { Domain: masalah kesehatan mental, } \\
\text { kelelahan, sulit untuk tertidur, frekuensi } \\
\text { berjalan, kesulitan berkonsentrasi. }\end{array}$ \\
\hline SF-6D & Australia & 3408 & $\begin{array}{l}\text { Baxter } \\
(2014)^{9}\end{array}$ & $\begin{array}{l}\text { Domain: fungsi fisik, keterbatasan peran, } \\
\text { fungsi sosial, rasa sakit, kesehatan } \\
\text { mental dan vitalitas. }\end{array}$ \\
\hline CASP-19 & $\begin{array}{l}\text { Republik } \\
\text { ceko, } \\
\text { Rusia }\end{array}$ & 210 & $\begin{array}{l}\text { Kim } \\
(2014)^{24}\end{array}$ & $\begin{array}{l}\text { Domain: kontrol, otonomi, kesenangan, } \\
\text { realisasi diri. }\end{array}$ \\
\hline SF-6D & Brazil & 5000 & $\begin{array}{l}\text { Campoli } \\
\text { na } \\
(2018)^{11}\end{array}$ & $\begin{array}{l}\text { Domain: fungsi fisik, keterbatasan peran, } \\
\text { fungsi sosial, rasa sakit, kesehatan } \\
\text { mental dan vitalitas. }\end{array}$ \\
\hline WEMWBS & Spanyol & 1900 & $\begin{array}{l}\text { Castellvi } \\
(2014)^{25}\end{array}$ & $\begin{array}{l}\text { Domain mental (Optimis dengan masa } \\
\text { depan,santai, ketertarikan dengan orang } \\
\text { lain, tenaga, menangani masalah, percaya } \\
\text { diri dll) }\end{array}$ \\
\hline QWB-SA & Tobago & 235 & $\begin{array}{l}\text { Hector } \\
(2008)^{26}\end{array}$ & $\begin{array}{l}\text { Mobilitas, Aktifitas fisik, aktivitas sosial } \\
\text { dan gejala yang pernah dirasakan. }\end{array}$ \\
\hline EQ-5D-5L & Jerman & 2469 & $\begin{array}{l}\text { Hinz } \\
(2013)^{13}\end{array}$ & $\begin{array}{l}\text { Domain: mobilitas, perawatan diri, } \\
\text { kegiatan yang biasa dilakukan, rasa } \\
\text { sakit, kesehatan mental. }\end{array}$ \\
\hline LEIPAD & Perancis & 195 & $\begin{array}{l}\text { Jalenque } \\
\text { S } \\
(2012)^{27}\end{array}$ & $\begin{array}{l}\text { Domain: Fungsi fisik, perawatan diri, } \\
\text { depresi dan kecemasan, fungsi cognitive, } \\
\text { fungsi seksual,fungsi sosial dan } \\
\text { kepuasaan akan hidup }\end{array}$ \\
\hline HINT-20 & Korea & 891 & $\begin{array}{c}\text { Jo } \\
(2017)^{28}\end{array}$ & $\begin{array}{l}\text { Domain: kesehatan fisik, kesehatan } \\
\text { sosial, kesehatan mental, kesehatan } \\
\text { positif, }\end{array}$ \\
\hline EQ-5D-5L & $\begin{array}{l}\text { Korea } \\
\text { selatan }\end{array}$ & 600 & $\begin{array}{l}\text { Kim } \\
(2012)^{14}\end{array}$ & $\begin{array}{l}\text { Domain: mobilitas, perawatan diri, } \\
\text { kegiatan yang biasa dilakukan, rasa } \\
\text { sakit, kesehatan mental. }\end{array}$ \\
\hline SF-36 & Asia & 4917 & $\begin{array}{l}\text { Thumbo } \\
\text { o }(2013)^{8}\end{array}$ & $\begin{array}{l}\text { Domain: fungsi fisik, keterbatasan peran } \\
\text { masalah fisik, nyeri badan, persepsi } \\
\text { kesehatan umum, vitalitas, fungsi sosial, } \\
\text { fungsi sosial, keterbatasan peran karena } \\
\text { faktor emosional, kesehatan mental. }\end{array}$ \\
\hline
\end{tabular}

11. Control Autonomy,Self-realisation, Pleasure scale (CASP) $)^{24}$

12. Warwick-Edinburgh Mental Well-Being Scale $(\text { WEMWBS })^{25}$

13. Quality-Well Being Self-Administration $\left(\right.$ QWB-SA) ${ }^{26}$

14. Leiden-Padua Questionnaire (LEIPAD) ${ }^{27}$
15. Health-Related Quality of Life Instrument with 20-items (HINT-20) 28

\section{Penilaian properti instrumen HRQOL}

Properti psikometrik merupakan hal yang penting dilakukan ketika pengukuran 
Tabel II. Kriteria Cohen Penilaian Psychometric Properties ${ }^{4}$

\begin{tabular}{lcc}
\hline Psychometric Properties & Rating & Kriteria \\
\hline Internal consistency & + & Cronbach alpha $>0,7$ \\
& - & Cronbach alpha $<0,7$ \\
Test-retest reliability & $?$ & Tidak diujikan \\
& + & Nilai ICC atau kappa $>0,7$ pearson-spearman's r $>0,7$ \\
& - & TCC,kappa, pearson-spearman's $<0,7$ \\
Content validity & $?$ & Tidak diujikan \\
& + & content validity dilakukan dengan tepat \\
Construct validity & - & tidak dilakukan dengan tepat \\
& $?$ & tidak diujikan \\
& + & Berkorelasi dengan hipotesis disertai statistik \\
Ceiling- effect & - & Korelasi $0,4-0,8$ \\
& $?$ & $<0,4-0,8$ \\
& + & Tidak diujikan \\
& - & $>15 \%$ responden dengan skor tertinggi \\
& $?$ & Tidak diujikan \\
\hline
\end{tabular}

Tabel III. Kriteria Cohen untuk Tingkat Kredibilitas Psychometric Properties ${ }^{4}$

\begin{tabular}{|c|c|}
\hline Kategori & Kriteria \\
\hline Penilaian yang baik (established) & $\begin{array}{ll}\text { I. Pengukuran } p \text { sychometric setidaknya dibahas dalam } \\
2 \text { artikel oleh peneliti yang berbeda atau tim peneliti } \\
\text { II. Pengukuran yang cukup detail, memungkinkan } \\
\text { dievaluasi dan repilkasi. } \\
\text { III. Menampilkan (statistik) terkait informasi validasi } \\
\text { dan reliabilitas yang baik setidaknya dalam } 1 \text { artikel } \\
\text { review. }\end{array}$ \\
\hline $\begin{array}{l}\text { mendekati } \\
\text { established) }\end{array}$ & $\begin{array}{l}\text { I. Pengukuran psychometric setidaknya dibahas dalam } \\
2 \text { artikel oleh peneliti yang sama/tim peneliti. } \\
\text { II. Pengukuran yang cukup detail, memungkinkan } \\
\text { dievaluasi dan repilkasi }\end{array}$ \\
\hline & $\begin{array}{l}\text { III. Informasi validasi dan reliabilitas disajikan } \\
\text { walaupun tidak lengkap (tidak menampilkan } \\
\text { statistik). }\end{array}$ \\
\hline Promising & $\begin{array}{l}\text { I. Pengukuran psychometric hanya dibahas dalam } 1 \\
\text { artikel. } \\
\text { II. Pengukuran yang cukup detail, memungkinkan } \\
\text { dievaluasi dan repilkasi. }\end{array}$ \\
\hline & $\begin{array}{l}\text { III. Informasi validasi dan reliabilitas disajikan } \\
\text { walaupun tidak lengkap (tidak menampilkan } \\
\text { statistik). }\end{array}$ \\
\hline
\end{tabular}

kualitas hidup (HRQoL) diukur menggunakan sebuah instrumen, instrumen yang valid dan reliabel sejatinya akan memberikan hasil pengukuran yang valid dan terpercaya. Sebuah validitas akan memberikan gambaran tentang kecermatan 
Restu Nur Hasanah Haris, et al

Tabel IV. Penilaian Psychometric Properties Instrumen HRQoL

\begin{tabular}{cccccc}
\hline $\begin{array}{c}\text { Instrumen } \\
\text { HRQoL }\end{array}$ & $\begin{array}{c}\text { Internal } \\
\text { consistency }\end{array}$ & $\begin{array}{c}\text { Test-retest } \\
\text { reliability }\end{array}$ & $\begin{array}{c}\text { Content } \\
\text { validity }\end{array}$ & $\begin{array}{c}\text { Construct } \\
\text { validity }\end{array}$ & $\begin{array}{c}\text { Ceiling } \\
\text { effect }\end{array}$ \\
\hline SF-6D & $? ?+$ & $-? ?$ & $? ? ?$ & +++ & $?+?$ \\
EQ-5D-5L & $? ? ?$ & $-?+$ & $? ? ?$ & +++ & -++ \\
SF-36 & + & $?$ & $?$ & + & - \\
VSP-A & - & - & + & + & - \\
WHOQOL- & -+ & $-?$ & $+?$ & ++ & $-?$ \\
BREF & & & & & \\
SF-12 & $?+$ & $? ?$ & $? ?$ & + & +- \\
PedsQL & ++ & $?+$ & $?+$ & ++ & $? ?$ \\
PMH & + & $?$ & $?$ & + & + \\
SIWB & + & + & + & - & $?$ \\
4DSQ & + & $?$ & $?$ & $?$ & $?$ \\
SF-36 & ++ & $? ?-$ & $? ? ?$ & $?-+$ & $-+?$ \\
WHO & + & - & $?$ & + & $?$ \\
CASP-19 & + & $?$ & $?$ & + & - \\
WEMWBS & + & - & $?$ & + & + \\
QWB-SA & $?$ & $?$ & + & + & $?$ \\
LEIPAD & + & + & + & + & - \\
HINT-20 & + & + & + & + & - \\
\hline
\end{tabular}

dan ketepatan dalam hasil pengukuran begitupula reliabilitas. Kedua aspek ini perlu kita interpretasikan agar bisa menilai pengukuran yang tepat, handal dan terpercaya. Dalam tinjauan ini, peneliti menilai properti psikometrik yang diujikan pada populasi umum. Berdasarkan tinjauan sistematik yang telah dilakukan pada 24 artikel, uji properti psikometrik tidak diujikan secara lengkap.

Untuk pengujian validasi, hanya beberapa instrumen yang menguji content validity. Sebelumnya beberapa instrumen telah melalui proses translation dari versi original ke bahasa lain yang kemudian content dari instrumen tersebut dinilai oleh para expert (FGD), menilai item-item pertanyaan dalam tiap domain dan melakukan pilot study/pre-test sebelum instrumen diujikan (face validity) PedsQL ${ }^{20}$ LEIPAD $^{27}$ HINT-2028, WHOQOLBREF ${ }^{16}$.Pengujian construct validity pada populasi umum kebanyakan menggunakan metode convergent validity dan discriminant validity SF-36 ${ }^{8}$, EQ-5D ${ }^{2912}$, WHOQOL-BREF1617, SF-1218, PedsQoL ${ }^{20}, \quad$ HINT-2028. Beberapa penelitian juga menggunakan pengujian construct dengan concurent validity, LEIPAD ${ }^{27}$, $\mathrm{PMIH}^{21}$ dimana hampir semua instrumen memberikan nilai yang baik dengan tingkat korelasi diatas 0,4-0,8 serta berkorelasi untuk tiap domain.

Untuk reliabilitas hasil menunjukan hampir setiap instrumen memberikan nilai cronbach alpha yang yang sempuran $(>0,7)$. Dikatakan bahwa pengujian dengan nilai cronbach alpha $>0,7$ memberikan hasil yang terbaik ${ }^{30}$. Test-retest reliability merupakan pengujian yang dilakukan dengan waktu berselang (2 minggu) yang kemudian diberikan kembali pada responden yang sama untuk menilai kehandalan sebuah instrumen, sedangkan internal consistency hanya dalam 1 kali pengujian dengan menggunakan interpretasi nilai dari cronbach alpha. Dalam tinjauan ini, beberapa instrumen melakukan pengujian reliabilitas dengan 2 metode sekaligus yakni uji internal consistency dan testretest reliability pada instrumen $\mathrm{VSP}^{15}$, WHOQOL-BREF ${ }^{16}$, PedsQL ${ }^{20}, \mathrm{SIWB}^{31}$, WHO ${ }^{23}$, WEMWBS 25 , LEIPAD ${ }^{27}$, HINT-2028, namun 
Tabel V. Penilaian Kredibilitas Instrumen

\begin{tabular}{|c|c|c|}
\hline Kategori & & Hasil Pengukuran \\
\hline Penilaian yang baik (established) & & SF-36 $6,6,6,8$, SF-6D ${ }^{9,10}$, EQ-5D ${ }^{13,14,29}$, SF-12 ${ }^{18}$, PedsQL20,19 \\
\hline $\begin{array}{l}\text { Mendekati } \\
\text { established) }\end{array}$ & well- & WHOQOL-BREF 16,32 \\
\hline Promising & & $\begin{array}{l}\text { VSP }{ }^{15}, \mathrm{WEMWBS}^{25}, \mathrm{LEIPAD}{ }^{27}, \mathrm{HINT} 20^{28}, \mathrm{WHO}^{23}, \mathrm{CASP}- \\
\text { 1924, }^{24} \mathrm{WB}^{26}, 4 \mathrm{DSQ}^{22}\end{array}$ \\
\hline
\end{tabular}

ada pula beberapa instrumen yang hanya menyertakan salah satu dari uji keduanya EQ5D-5L ${ }^{14}$, SF- $36^{5}, \mathrm{PMH}^{21}$, SF-12 ${ }^{18}, 4 \mathrm{DSQ}^{22}$, CASP1924.Pilihan untuk melakukan uji reliabilitas dengan metode tertentu tergantung rancangan penelitian dan tujuan sebuah penelitian itu sendiri, tidak ada ketentuan dalam penggunaan metode reliabilitas yang akan digunakan, hanya saja beberapa literatur menuliskan bahwa pengujian dengan internal consistency dapat meminimalisir kesalahan yang biasa ditimbulkan dalam pengujian testretest reliability karena interval waktu dalam pemberian kuesioner yang tidak tentu sehingga mempengaruhi hasil reliabilitas, dan bisa saja terjadi carry over effect ${ }^{30}$.

Beberapa instrumen dalam tinjauan sistematik ini menilai adanya ceiling effect. Dikatakan bahwa instrumen dengan content yang baik tidak memiliki ceiling effect. Pengujian ceiling effect dimaksudkan untuk melihat bagaimana distribusi jawaban responden. Ketika responden (>15\%) menjawab dengan angka sempurna maka dapat dikatakan bahwa instrumen tersebut memiliki ceiling effect. Dari hasil tinjauan sistematik ini, instrumen SF-36,6,6, VSP-A $^{15}$, $\mathrm{CASP}^{24}$ dan HINT-2028 dilaporkan memiliki ceiling effect $(>15 \%)$, sedangkan SF-6D', EQ$5 \mathrm{D}^{12,14}$ dan WEMWBS 25 tidak memiliki ceiling effect $(<15 \%)$.

\section{Penilaian kredibilitas instrumen HRQOL}

Selain menilai properti psikometrik yang diujikan pada beberapa instrumen HRQoL pada populasi umum, dalam review ini peneliti juga menilai bagaimana tingkat kredibilitas instrumen yang digunakan. Hasil penilaian kami dengan menggunakan kriteria cohen $^{33}$ bahwa instrumen Short Form-36 (SF36), Short Form 6-Dimension (SF-6D), European Quality-Five Dimension (EQ-5D), Short Form-12 (SF-12), Pediatric Quality of life (PedsQL) dinilai sebagai instrumen yang established, Instrumen WHOQOL-BREF dinilai sebagai penilaian yang mendekati established dan instrumen lainnya dinilai sebagai instrumen yang menjanjikan. Penilaian ini didasarkan pada jumlah publikasi yang banyak dilakukan oleh peneliti lain menggunakan instrumen tersebut, serta memberikan penyajian properti psikometrik yang baik pada beberapa penelitian. Bila ditinjau dari segi penggunaannya, jenis Instrumen Short Form36 (SF-36), Short Form 6-Dimension (SF-6D), European Quality-Five Dimension (EQ-5D), Short Form-12 (SF-12) dan PedsQL merupakan jenis instrumen generik yang pada dasarnya sering digunakan untuk menilai kualitas hidup (HRQoL) baik pada populasi umum diberbagai negara dan berbagai etnis maupun penilaian spesifik pada pasien tertentu. Sehingga tingkat kredibilitas instrumen tersebut dapat dikatakan baik dalam mengukur sebuah kualitas hidup, Instrumen lainnya dapat menjadi pertimbangan dalam pengukuran kualitas hidup (HRQoL).

Penilaian properti psikometrik yang dilakukan mungkin saja memberikan nilai ataupun hasil yang berbeda oleh peneliti lainya, belum ada kesepakatan ataupun definisi properti psikometrik yang perlu dan wajib untuk dilakukan, tetapi pada dasarnya dalam tinjauan sistematik ini dapat dikatakan bahwa sebuah instrumen yang mengukur sebuah kualitas hidup (HRQoL) baik itu pada populsi umum maupun pada popolasi pasien tertentu harus memberikan validitas dan 
tingkat reliabilitas yang baik guna memberikan hasil pengukuran yang tepat dan terpercaya. Hasil tinjauan kami secara keseluruhan, dalam penilaian properti psikometrik instrumen HRQoL khususnya pada populasi umum belum sempurna dilakukan karena masih ada beberapa metode yang belum diujikan, hasil yang didapatkan tidak disajikan dan dijelaskan dengan tepat serta belum memenuhi kriteria cohen. Beberapa instrumen tidak melakukan content validity, test-retest reliability dan penilaian ceiling effect sehingga kedepannya diperlukan pengujian dalam penelitian selanjutnya.

Keterbatasan dalam penelitian ini adalah penilaian properti psikometrik yang dilakukan belum mencakup keseluruhan metode, hanya terkait penilaian content validity, construct validity, reliabilitas dan penilaian ceiling effect. Untuk memberikan penilaian yang lebih baik diperlukan metode penilaian seperti responsivitas, faktor analisis dan interpretabilitas. Artikel yang dinilai terbatas hanya dalam artikel berbahasa inggris, penilaian juga hanya menilai dari segi pengukuran properti psikometrik yang diperoleh dan tingkat kredibilitas instrumen yang digunakan dengan menggunakan kriteria cohen. Untuk kedepannya, penelitian selanjutnya dapat menilai dari aspek lain yang lebih luas dan pada populasi spesifik tertentu.

\section{KESIMPULAN}

Hasil penilaian properti psikometrik instrumen HRQoL pada populasi umum adalah beberapa instrumen belum memenuhi dan melakukan pengujian sesuai kriteria yang ada. Instrumen HRQoL yang paling banyak digunakan pada populasi umum adalah SF-36. Tinjauan terkait validasi masing-masing memberikan hasil yang baik dengan tingkat reliabilitas yang tinggi dimana cronbach alpha $>0,7$ dan penilaian ceiling effect yang rendah. Instrumen Short Form-36 (SF-36), Short Form-6 Dimension (SF-6D), European Quality-Five Dimension (EQ-5D), Short Form-12 (SF-12) dan Pediatric Quality of Life (PedsQoL) dinilai sebagai instrumen yang established. Diperlukan pengujian validasi lebih lanjut untuk memberikan dan mendukung pengukuran instrumen HRQoL selanjutnya.

\section{DAFTAR PUSTAKA}

1. Augustin M., Conde Montero E., Zander N., et al., Validity and feasibility of the wound-QoL questionnaire on health-related quality of life in chronic wounds. Wound Repair Regeneration 2017;25(5):852-857.

2. Cruz LN., Camey SA., Hoffmann JF., et al., Estimating the SF-6D value set for a population-based sample of Brazilians.2011;14(5 Suppl 1):S108-114.

3. Walters SJ. Quality of Life Outcomes in Clinical Trials and Health-Care Evaluation: A Practical Guide to Analysis and Interpretation. John Wiley \& Sons; 2009.

4. Terwee CB., Mokkink LB., Knol DL., Ostelo RWJG., Bouter LM., de Vet HCW. Rating the methodological quality in systematic reviews of studies on measurement properties: a scoring system for the COSMIN checklist. Quality of Life Research . 2012;21(4):651657.

5. Kangwanrattanakul K., Auamnoy T. Psychometric testing of the healthrelated quality of life measurement, SF$36 \mathrm{v} 2$, in the general population of Thailand. Expert Rev Pharmacoecon Outcomes Res. October 2018:1-8.

6. Garratt AM., Stavem K. Measurement properties and normative data for the Norwegian SF-36: results from a general population survey. Health Quality of Life Outcomes. 2017;15(1):51.

7. Khader S., Hourani MM., Al-Akour N. Normative data and psychometric properties of short form 36 health survey (SF-36, version 1.0) in the population of north Jordan. East Mediterr Health Journal. 2011;17(5):368374.

8. Thumboo J., Wu Y., Tai E-S., et al., Reliability and validity of the English (Singapore) and Chinese (Singapore) versions of the Short-Form 36 version 2 in a multi-ethnic urban Asian 
population in Singapore. Quality of Life Research. 2013;22(9):2501-2508.

9. Baxter S., Sanderson K., Venn A., Otahal P, Palmer AJ. Construct validity of SF6D health state utility values in an employed population. Quality of Life Research .2015;24(4):851-870.

10. Lam CLK., Brazier J., McGhee SM. Valuation of the SF-6D Health States Is Feasible, Acceptable, Reliable, and Valid in a Chinese Population. Value Health J Int Soc Pharmacoeconomics Outcomes Res. 2008;11(2):295-303.

11. Campolina AG., López RVM., Nardi EP., Ferraz MB. Internal Consistency of the SF-6D as a Health Status Index in the Brazilian Urban Population. Value Health Reg Issues. 2018;17:74-80.

12. Shafie AA., Vasan Thakumar A., Lim CJ., Luo N. Psychometric performance assessment of Malay and Malaysian English version of EQ-5D-5L in the Malaysian population. Quality of Life Research. October 2018.

13. Hinz A., Kohlmann T., Stöbel-Richter Y., Zenger M, Brähler E. The quality of life questionnaire EQ-5D-5L: psychometric properties and normative values for the general German population. Quality of Life Research.2014;23(2):443-447.

14. Kim TH., Jo M-W., Lee S., Kim SH., Chung SM. Psychometric properties of the EQ-5D-5L in the general population of South Korea. Quality of Life Research. 2013;22(8):2245-2253.

15. Aires MT., Auquier P., Robitail S., Werneck GL., Simeoni M-C. Crosscultural adaptation and psychometric properties of the Brazilian-Portuguese version of the VSP-A (Vécu et Santé Perçue de l'Adolescent), a healthrelated quality of life (HRQoL) instrument for adolescents, in a healthy Brazilian population. BMC Pediatr. 2011;11:8.

16. Nedjat S., Montazeri A., Holakouie K., Mohammad K., Majdzadeh R. Psychometric properties of the Iranian interview-administered version of the World Health Organization's Quality of Life Questionnaire (WHOQOL-BREF): a population-based study. BMC Health Serv Res. 2008;8:61.

17. Suárez L., Tay B., Abdullah F. Psychometric properties of the World Health Organization WHOQOL-BREF Quality of Life assessment in Singapore. Quality of Life Research. 2018;27(11):29452952.

18. Kim S-H., Jo M-W., Ahn J., Ock M., Shin S., Park J. Assessment of psychometric properties of the Korean SF-12 v2 in the general population. BMC Public Health. 2014;14:1086.

19. Limperg PF., Haverman L., van Oers HA., van Rossum MAJ., Maurice-Stam H., Grootenhuis MA. Health related quality of life in Dutch young adults: psychometric properties of the PedsQL generic core scales young adult version. Health Quality Life Outcomes. 2014;12:9.

20. Ferreira PL., Baltazar CF., Cavalheiro L., Cabri J., Gonçalves RS. Reliability and validity of PedsQL for Portuguese children aged 5-7 and 8-12 years. Health Quality of Life Outcomes. 2014;12:122.

21. Vaingankar JA., Subramaniam M., Tan LWL., et al., Psychometric properties and population norms of the positive mental health instrument in a representative multi-ethnic Asian population. BMC Med Res Methodol. 2018;18(1):29.

22. Terluin B., Smits N., Brouwers EPM., de Vet HCW. The Four-Dimensional Symptom Questionnaire (4DSQ) in the general population: scale structure, reliability, measurement invariance and normative data: a cross-sectional survey. Health Quality of Life Outcomes. 2016;14(1):130.

23. Löve J., Andersson L., Moore CD., Hensing G. Psychometric analysis of the Swedish translation of the WHO wellbeing index. Quality of Life Research. 2014;23(1):293-297. 
24. Kim GR., Netuveli G., Blane D., et al., Psychometric properties and confirmatory factor analysis of the CASP-19, a measure of quality of life in early old age: the HAPIEE study. Aging Ment Health. 2015;19(7):595-609.

25. Castellví P., Forero CG., Codony M., et al., The Spanish version of the WarwickEdinburgh mental well-being scale (WEMWBS) is valid for use in the general population. Quality of Life Research. 2014;23(3):857-868.

26. Hector RD., Anderson JP., Paul RCP., et al., Evaluation of the validity of the Quality of Well-being Scale in Trinidad and Tobago. West Indian Med J. 2008;57(2):135-140.

27. Jalenques I., Auclair C., Roblin J., et al., Cross-cultural evaluation of the French version of the LEIPAD, a health-related quality of life instrument for use in the elderly living at home. Quality of Life Research. 2013;22(3):509-520.

28. Jo M-W., Lee H-J., Kim SY., et al., Development and Validation of a Novel
Generic Health-related Quality of Life Instrument With 20 Items (HINT-20). J Prev Med Public Health Yebang Uihakhoe Chi. 2017;50(1):38-59.

29. Wu C., Gong Y., Wu J., et al., Chinese Version of the EQ-5D Preference Weights: Applicability in a Chinese General Population. PloS One. 2016;11(10):e0164334.

30. Gregory., R.J. Tes Psikologi Sejarah, Prinsip Dan Aplikasi. Jakarta: Erlangga; 2013.

31. Wu L-F., Yang S-H., Koo M. Psychometric properties of the Chinese version of Spiritual Index of Well-Being in elderly Taiwanese. BMC Geriatr. 2017;17(1):3.

32. Saqib Lodhi F., Raza O, Montazeri A., Nedjat S., Yaseri M., Holakouie-Naieni K. Psychometric properties of the Urdu version of the World Health Organization's quality of life questionnaire (WHOQOL-BREF). Med J Islam Repub Iran. 2017;31:129. 